\title{
COMPETENCIES ON EXECUTION OF VILLAGE GOVERNMENT AUTHORITIES, TRANSPARENCY, PUBLIC PARTICIPATION AND ACCOUNTABILITY OF VILLAGES FUND MANAGEMENT
}

\author{
${ }^{1}$ Shinta N. Nazar, ${ }^{2}$ Rosita Wulandari, ${ }^{3}$ Syafrizal, ${ }^{4}$ Ayu Lestari \\ 1,2,3,4 Universitas Pamulang, Tangerang Selatan, Banten, Indonesia \\ Email:dosen00801@unpam.ac.id
}

\begin{abstract}
Authorities, transparency, and public participation to the accountability of village fund management and finds the obstacles to its implementation. This Research using multiple regression analysis, with convenience sampling and using questioners. Results show competencies on execution of village government authorities have effect negative and significant, contrary to Transparency have positive and significant, but Public Participation does not have effects. According to the result, competencies on execution of village government authorities still low, villagers knows about village funds in Kecamatan Tigaraksa because they all get the benefit from village fund, and they only follow the instructions.
\end{abstract}

Keywords: Accountability of Village Fund Management; Competencies on Execution of Village Government Authorities; Transparency; Public Participation

\section{INTRODUCTION}

Indonesia as a country built on and from the village, the village has extraordinary local nobility and wisdom, and also respectability and shrewdness. The village is the pioneer of a democratic system that is fully autonomous and sovereign. Law No.6 Of 2014 of Republic Indonesia concerning villages mandates the government to allocate village funds to every administrative village in
Indonesia with a minimum amount of 10 percent from and outside the regional transfer funds that are given in stages. The village fund assignment that's channeled by the government to the village is certainly anticipated to be able to assist village improvement (Riskasari, 2016).

UU no. 6 of 2014 concerning villages, which contains village funds, which are funds sourced from the state income and consumptions budget allocated to villages that are 
EAJ (Economics and Accounting Journal) - Vol. 4, No. 1, Jan 2021 - Nazar, et al.

distributed through the district/city regional income and expenditure budget and are utilized to fund government organization, usage, advancement, and community strengthening. Every village that receives village funds is required to report the use of village funds as a form of accountability for village funds and good governance.

The comes about of the assessment of the utilize of village reserves within the, to begin with, semester of 2016 is still encountering issues. These problems include the use of village funds outside the priority areas, the expenditure of village reserves isn't upheld by satisfactory prove, development work is carried out completely by third parties/benefit suppliers, overpayments, collection, and installment of charges are not suitable, stores are put away not in Rekening Kas Desa and costs exterior the APBDesa (Service of Fund of the Republic of Indonesia, 2016: 19). (Gamaliel, 2017), so it is vital to control the administration of town reserves within the shape of great budgetary responsibility.

Accountability becomes a full control of the apparatus over everything that has been done in a government so that the role of the government as an agent becomes an important factor in accounting for the performance of the government to the principal or the people (Diarespati, 2017) so that complete accountability is needed. supporting factors in the village in the form of Competencies on Performance of Village Government Officials, transparency, and public participation.

The Competencies on execution of village government authoritiesis an important component in the process of a government activity, these government institutes are state administrative instruments that are tasked with providing public services as well as security and public order services (Adisasmito, 2014). Faridah (2015) appears that straightforwardness influences the responsibility of Village Support Allotment administration, great administration and paying consideration to the standards of straightforwardness and responsibility at the village government level as a result of village independence. Septianis (2012) public participation can affect the success or failure of the Village Fund Allocation program, this is evidenced by community activities, people voluntarily protect and maintain their own environment with their own responsibility and awareness without coercion from any party.

In 2015 the Banten provincial government distributed village fund allocations. Attachment XXII of Presidential Regulation Number 36 of 2015 concerning Details of the 2015 FY State Budget is Rp. $352,516,368,000$, of the 4 districts mentioned above, Lebak Regency, Pandeglang Regency, Serang Regency and Tangerang Regency. 
EAJ (Economics and Accounting Journal) - Vol. 4, No. 1, Jan 2021 - Nazar, et al.

This study took the population in Tangerang district with a focus on Tigaraksa sub-district because the author resides in Tangerang Regency, The receipt of village funds in Tigaraksa has been effective and wants to examine the direct effects of village funds in Tangerang Regency with an allocation of village funds of Rp. 75,128,048,000, so this research wants to obtain empirical evidence and influence partially and simultaneously on the Competencies on Performance of Village Government Officials, transparency, public participation Accountability of Villages Fund Management in Tangerang Regency.

This study aims to provide empirical evidence of the influence of Competencies on Performance of Village Government Officials, transparency, and community participation on Accountability of Villages Fund Management in the Tangerang District, Tigaraksa District partially and simultaneously. The benefits of this research for the villagers can encourage accountable management of villagers funds through increasing the competence of villagers fund management officials, transparency, and public participation.

\section{LITERATURE REVIEW AND HYPOTHESIS DEVELOPMENT}

Agency theory is a theory explaining the relationship between agencies that arises when the owner of the company gives authority to management to use company resources in running the company. This theory was first introduced by Jensen and Meckling in 1976 (Godrey et al: 2010). Agency theory is a concept that explains the contractual relationship between principals and agents. In local government in Indonesia, consciously or not, agency theory has actually been put into practice. In public sector organizations, principals are the people and agents are the government, in this case the village head and other village officials.

UU no. 6 of 2014 concerning towns, which contains village reserves, which are stores sourced from the state income and consumption budget apportioned to villages that are exchanged through the locale / city territorial wage and use budget and are utilized to back government organization, usage, improvement, community improvement, and community strengthening. Each village that gets town reserves is required to report the utilize of village reserves as a frame of responsibility for village reserves and great administration.

Darmiasih et al (2015) Village Finance Allotment (Include) may be a stimulant help or stimulant finance to empower financing of town government programs bolstered by community self-help interest in 
EAJ (Economics and Accounting Journal) - Vol. 4, No. 1, Jan 2021 - Nazar, et al.

carrying out government activities and community strengthening. Faridah (2015) Include may be a support apportioned by the locale / city government for village, which comes from the parcel of the central and territorial budgetary adjust stores gotten by the locale / city.

The Indonesian government continues to strive to increase the implementation of National Development so that the pace of regional development and the pace of rural and urban development is more balanced and harmonious. In the implementation of village governance, it is required that there is an aspect of good governance (Good Governance), where one of the main characteristics or elements of good governance is accountability. Accountability can be interpreted as a form of responsibility for the implementation of the organization's mission in achieving the stated goals through the accountability media which is carried out periodically. So, government accountability is needed to support the implementation of village autonomy so that it can run well.

State Organization Office and the Indonesian Monetary and Improvement Supervisory Office (2000: 12), responsibility is the commitment to supply responsibility or reply and clarify the execution and activities of a individual / pioneer of an organizational unit to parties who have the proper or are authorized to inquire responsibility within the frame of a report with the guideline that each town budgetary administration movement must be responsible to the town community, in understanding with statutory controls and is critical to guarantee the values of productivity, adequacy, and unwavering quality in town budgetary announcing which contains exercises, from arranging to realization or usage. Astuti (2016)

McClelland in Sagala and Rivai (2009) characterizes competency as a essential characteristic that somebody has that straightforwardly influences or can anticipate great execution. In other words, competence is what extraordinary entertainers do more regularly in more circumstances with superior comes about than what normal entertainers do.

Wida (2016) Straightforwardness is giving open, genuine, and nondiscriminatory money related data to the open based on the thought that the open has the proper to know transparently and completely the government's duty in overseeing the assets endowed to it and its compliance with laws and directions.

Mentari (2017) open interest is one of the variables that impact the victory of improvement programs and advancement of provincial communities. Community cooperation is required to realize town improvement in agreement with 
EAJ (Economics and Accounting Journal) - Vol. 4, No. 1, Jan 2021 - Nazar, et al.

the wants of the town itself. Community cooperation does not as it were include the community in making choices in each development

program, but the community is additionally involved in distinguishing issues and possibilities that exist within the community.

\section{Table 1. Previous Research}

\begin{tabular}{|c|c|c|c|}
\hline No & Name & Variable & Research result \\
\hline 1 & $\begin{array}{l}\text { Transparency and } \\
\text { accountability of the } \\
\text { financial management of } \\
\text { village fund allocation } \\
\text { (ADD) in achieving Good } \\
\text { Governance (Hamid, } \\
\text { 2016) }\end{array}$ & $\begin{array}{l}\text { X1 = transparency system, } \\
\text { X2 =accountability } \\
\text { planning, implementation, } \\
\text { accountability and } \\
\text { supervision } \\
Y=\text { ADD in Bontomaranu } \\
\text { District, Gowa Regency in } \\
\text { achieving Good } \\
\text { Governance }\end{array}$ & $\begin{array}{l}\text { The ADD planning stage in } 3 \\
\text { (villages) has implemented the } \\
\text { principles of participation and } \\
\text { transparency. This is } \\
\text { evidenced by the enthusiastic } \\
\text { presence of the community at } \\
\text { the village deliberation forum. }\end{array}$ \\
\hline 2 & $\begin{array}{l}\text { Accountability for } \\
\text { managing the allocation } \\
\text { of funds in Bongki } \\
\text { Lengkese Village, East } \\
\text { Sinjai District, Sinjai } \\
\text { Regency (Riskasari, } \\
2016 \text { ) }\end{array}$ & $\begin{array}{l}\mathrm{X} 1=\text { Village officials } \\
\mathrm{Y}=\text { Accountability of } \\
\text { village fund allocation }\end{array}$ & $\begin{array}{l}\text { The application of the } \\
\text { principle of accountability for } \\
\text { the management of village } \\
\text { fund allocations in Bongki } \\
\text { Lengkese Village based on the } \\
\text { indicator of public policy } \\
\text { accountability (policy decision } \\
\text { accountability) by Nico is } \\
\text { sufficient with the } \\
\text { understanding of village } \\
\text { officials regarding their duties } \\
\text { and functions. }\end{array}$ \\
\hline 3 & $\begin{array}{l}\text { The influence of } \\
\text { competence and internal } \\
\text { control systems on village } \\
\text { government } \\
\text { accountability in } \\
\text { managing village fund } \\
\text { allocation (ADD) } \\
\text { (Diarespati, 2017) }\end{array}$ & $\begin{array}{l}\mathrm{X} 1=\text { system competence } \\
\mathrm{X} 2=\text { internal control, } \mathrm{Y}= \\
\text { village government } \\
\text { accountability in managing } \\
\text { village fund allocations }\end{array}$ & $\begin{array}{l}\text { Application of competency } \\
\text { factors and government } \\
\text { internal control systems using } \\
\text { the Accountability Framework, } \\
\text { Constraints faced by village } \\
\text { government officials to } \\
\text { improve accountability in } \\
\text { managing village fund } \\
\text { allocations }\end{array}$ \\
\hline
\end{tabular}


EAJ (Economics and Accounting Journal) - Vol. 4, No. 1, Jan 2021 - Nazar, et al.

\begin{tabular}{|c|c|c|c|}
\hline 4 & $\begin{array}{l}\text { The influence of village } \\
\text { fund management } \\
\text { apparatus competence, } \\
\text { commitment of village } \\
\text { government } \\
\text { organizations and } \\
\text { community participation } \\
\text { on the accountability of } \\
\text { village fund management } \\
\text { in Gorontalo District } \\
\text { (Gamaliel, 2017) }\end{array}$ & $\begin{array}{l}\mathrm{X} 1=\text { Competence of } \\
\text { village fund management } \\
\text { officers, } \\
\mathrm{X} 2=\text { commitment of } \\
\text { village government } \\
\text { organizations, } \\
\mathrm{X} 3=\text { society participation, } \\
\mathrm{Y}=\text { accountability for } \\
\text { village fund management }\end{array}$ & $\begin{array}{l}\text { The competence of the } \\
\text { village fund management } \\
\text { apparatus, the commitment of } \\
\text { village government } \\
\text { organizations and community } \\
\text { participation have been } \\
\text { accounted for. }\end{array}$ \\
\hline 5 & $\begin{array}{l}\text { Factors that affect the } \\
\text { accountability of the } \\
\text { management of village } \\
\text { fund allocations (study at } \\
\text { the village office in } \\
\text { Ponorogo Regency) } \\
\text { (Niken, 2017) }\end{array}$ & $\begin{array}{l}\mathrm{X} 1 \text { = Apparatus resources, } \\
\mathrm{X} 2=\text { Transparency, } \\
\mathrm{X} 3 \text { = society participation } \\
\mathrm{Y}=\text { accountability for } \\
\text { village fund budget } \\
\text { management }\end{array}$ & $\begin{array}{l}\text { Apparatus resources have a } \\
\text { significant positive effect on } \\
\text { accountability for ADD } \\
\text { management accountability, } \\
\text { transparency has a significant } \\
\text { positive effect on ADD } \\
\text { management accountability, } \\
\text { community participation has } \\
\text { no effect on ADD management } \\
\text { accountability }\end{array}$ \\
\hline
\end{tabular}

The Effect of Competencies on execution of village government authorities on Accountability of Villages Fund Management

Competence is a factor that can affect accountability. To increase accountability requires competence (Frink and Klimoski, 2014: 14). This opinion is in line with several studies. This research was conducted by Subroto (2009), Irma (2015), Fajri (2015), Aziz (2016), Ferina (2016), Dewi (2016), and Makalalag (2017). The results of the study stated that the competence of human resources was one of the factors that influenced the accountability of village fund management.

The Effect of Transparency on Accountability of Villages Fund Management
Transparency is a factor affecting accountability. This research was conducted by Faridah (2015), Riyanto (2015), Umami (2017), and Nurodin (2017). The results of this study state that transparency is one of the factors that affects the accountability of village fund management.

\section{The Effect of Public Participations on Accountability of Villages Fund Management}

According to Crook and Sverrison in Devas and Grant (2003: 309) Accountability can be strengthened through increasing community participation. As a key to increasing the responsiveness of local governments to the poor, and to make development more pro-poor. As a mechanism for accountability, 
EAJ (Economics and Accounting Journal) - Vol. 4, No. 1, Jan 2021 - Nazar, et al.

participation is carried out starting from evaluation reporting (Ebrahim, 2003: 818). As in Los Angeles, participation is a way of enhancing accountability in response to growing public distrust of government. Many citizens blame officials for making decisions (Kim and Schachter, 2013: 462). The research was conducted by Septianis (2012), Ainnurohma (2014), Karimah et al (2013), Novia (2015), Jurniadi (2015).

\section{RESEARCH METHOD}

This study used a descriptive method with a quantitative approach. The population of this study was all village in kecamatan Tigaraksa. The sampling technique is convinience sampling. Total sample involve this study is 10 village Tigaraksa, sampling method use convinience sampling,. The respondents obtained is as many as 91 individuals

This study uses primary data in the form of a questionnaire. The sampling collection technique used convinience sampling. The object of this research is the apparatus and villagers of Tangerang Regency, Tigaraksa District as respondents, the responses of respondents in the form of questionnaires will be analyzed using multiple linear regression analysis techniques, because the research consists of a dependent variable of one metric and two or more metric independent variables, the stages start from the descriptive statistical measurement method., data quality test, classical assumption test, $\mathrm{t}$ test and $\mathrm{F}$ count test as well as correlation coefficient and determination.

Table 2. Variable Measurement

\begin{tabular}{ll}
\hline Variable & Dimension \\
\hline $\begin{array}{l}\text { Competencies on Performance of } \\
\text { Village Government Officials }\end{array}$ & $\begin{array}{l}\text { Knowledge of training } \\
\text { Ability to find solution } \\
\text { Initiative }\end{array}$ \\
\hline Transparency & Acsessibility to information \\
& Honest and no discrimination \\
\hline Public Participation & $\begin{array}{l}\text { Involved in village programme } \\
\text { Involved in budgeting } \\
\text { Give valuation in bugeting } \\
\text { trust from villagers to } \\
\text { government }\end{array}$ \\
\hline
\end{tabular}


EAJ (Economics and Accounting Journal) - Vol. 4, No. 1, Jan 2021 - Nazar, et al.

$\begin{array}{ll}\begin{array}{l}\text { Accountability of Villages Fund } \\ \text { Management }\end{array} & \text { Compliance } \\ & \text { on time in financial statement } \\ & \text { accomplished village aim } \\ & \text { benefit village fund to public }\end{array}$

The variables used in this study consisted of dependent variable and independent variabels. The dependent variabel is the variable that is target of this study. The dependent variabel examined in this study is Accountability of Villages Fund Management. Independent variabel are variabels that affects the dependent variabel, while the independent variabel used in this study include : Competencies on execution of village government authorities(X1), Transparency (X2), Public Participation (X3). The method of data analysis in this research in Multiple Regression
Analysis. The research data was processed using SPPS

\section{RESULTS AND DISCUSSION}

Descriptive Data Analysis

The comes about of clear measurable investigation point to portray the dispersion of the comes about of questionares with respect to inquire about factors, particularly on all markers. In this think about graphic statstics can be seen within the least, most extreme, normal, and standard deviation esteem.

Table 3. Descriptive Variables

\begin{tabular}{|c|c|c|c|c|}
\hline Variabel & Minimum & $\begin{array}{l}\text { Maximu } \\
\text { m }\end{array}$ & Mean & $\begin{array}{c}\text { Std. } \\
\text { Deviation }\end{array}$ \\
\hline$\left(\mathrm{X}_{1}\right)$ & 18 & 40 & 28,31 & 6,575 \\
\hline$\left(\mathrm{X}_{2}\right)$ & 24 & 40 & 32,61 & 4,483 \\
\hline$\left(\mathrm{X}_{3}\right)$ & 19 & 40 & 32,00 & 4,595 \\
\hline$(\mathrm{Y})$ & 31 & 50 & 41,39 & 5,896 \\
\hline
\end{tabular}

All factors appeared, the normal esteem of the respondent's reply is more prominent than standard deviation, demonstrating that the factors have a great cruel esteem which is nice representation of the investigate information.

\section{Multiple Linear Regression Analysis}

Multiple linear regression analyses were performed to predict te relationship between independent variabels and dependent variabels 
EAJ (Economics and Accounting Journal) - Vol. 4, No. 1, Jan 2021 - Nazar, et al.

Table 4. Result

\begin{tabular}{|c|c|c|}
\hline Variables & B & Sig \\
\hline $\mathrm{X} 1$ & -0.493 & 0,000 \\
\hline $\mathrm{X} 2$ & 0,296 & 0,005 \\
\hline \multirow[t]{2}{*}{$\mathrm{X} 3$} & 0.196 & 0,055 \\
\hline & & Sig \\
\hline Y & 23,274 & 0,000 \\
\hline $\mathrm{K} / \mathrm{S}$ Test & 0,200 & \\
\hline R square & 0,421 & \\
\hline
\end{tabular}

Based on information stated in table 4 , it indicates that $\mathrm{X} 1$ have negatively $(-0,493)$ and significance influence to $\mathrm{Y}(\mathrm{p}<0,05)$. It means Competencies on execution of village government authoritiesstill low in kecamatan Tigaraksa,this is due to inefectiveness of the training system from Tigaraksa sub-district government on accountability of village fund management and low level of competence and education, based on the result some of the respondents dominated by high school graduates. The results are consistent with the previous researchers (Diarespati, 2017)

According to $\mathrm{X} 2$ to $\mathrm{Y}$, it can be concluded that the higher transparancy, the higher the accountability of village management, which means that it has significant effect on the accountability of village fund management. The results of this study are suported by previous research conducted by Niken (2017) and Hamid (2016) which shows that the transparancy variable has a significant possitive effect on the accountability of village fund management. This is caused by the community in accessing the widest possible infromation about of villagers finance.

From $\mathrm{X} 3$ to $\mathrm{Y}$, it can be concluded that the higher public participation, the higher the accountability of village fund management, meaning that public participation does not have a critical impact, which isn't the most figure within accountability of village fund management. This can be since the community does not truly get it the town finance, the community as it were takes after what is educating without knowing how much village reserves are gotten and its utilize. However, it is opposite to past investigate conducted by Gamaliel (2017) which appears that the community perticipation variable contains a noteworthy positive impact on the responsibility of town support administration

\section{CONCLUSION}

Competencies on Execution of Village Government Authorities have a negative influence and significant over the accountability village funds management. This shown through the result of significance an individually shows the thitung of $-7,025$ greater than ttabel of 1,985 ( thitung \& gt; ttabel ) and the level significance of 0,000 no more than 0.05 . The result of 
EAJ (Economics and Accounting Journal) - Vol. 4, No. 1, Jan 2021 - Nazar, et al.

this research supported by research before done diarespati ( 2017 ) who showed that variable competence management officials village funds have a negative influence over the accountability management significant village funds . Transparency significant over the accountability village funds management .It can be seen through the results of the significance an individually shows the T-count of 2,872 greater than ttabel of 1,985 ( thitung \& gt; ttabel ) and the level significance 0,005 no more than 0.05 .The result of this research, supported by research formerly practiced by niken (2017). Public participation will not affect accountability village funds management.It can be seen from the results of the significance through an individually shows $\mathrm{T}$ count of 1,941 smaller than ttabel of 1,985 (T-count \& it; ttabel ) and the significance 0,055 more than 0,05.Results supported by 2017 niken ( said ) community participation no effect significantly to accountability village funds management .Competence fund management officials village, transparency, and community participation together influential over the accountability village funds management indicated through the results of the significance simultaneous ( test $f$ to the value of $f$ count of 23,274 greater than ftabel of 2,70 and the level significance of 0,000 are much smaller than 0.05 .

\section{REFERENCES}

Astuti. (2016). Pengaruh Sistem Pengendalian Intern terhadap Kualitas Laporan Keuangan Implikasinya Terhadap Akuntabilitas Kinerja Instansi Pemerintah (Survei Pada Dinas Kota Badung. Elib. Unikom. Hal 31.

Aziz, Nyimas Latifah Letty. (2016). Otonomi Desa dan Efektivitas Dana Desa. Jurnal Penelitian Politik, Vol.13, No.2 Hal. 193211.

Bicu, YS. (2013). Kamus Bahasa Indonesia. Jakarta : Citra Harta Prima.

BPKP. (2016). Petunjuk Pelaksanaan Bimbingan \& Konsultasi Pengelolaan Keuangan.

Devas, Nick. (2003). Local Governent Decision MakingCitizen Participation and Local Accountability. Public Administration and Development, Hal 307-306.

Dewi, Retno Astuti. (2016). FaktorFaktor yang Berpengaruh terhadap Kinerja Keuangan Pemerintah Desa Pasca Penerapan Undang-Undang Nomor 6 Tahun 2014. Jurnal Akuntansi Aktual, Vol. 3, No.6 Hal 311-327.

Diarespati. (2017). Pengaruh Kompetensi dan Sistem Pengendalian Internal Terhadap Akuntabilitas 
EAJ (Economics and Accounting Journal) - Vol. 4, No. 1, Jan 2021 - Nazar, et al.

Pemerintah Desa Dalam Mengelola Alokasi Dana Desa (ADD, Journal of Public Finance and management11 (4) :306-337).

Ebrahim, Alnoor. (2003). Accountability In Practice: Mechanisms for NGO's. World Development 31 (5), Hal 818.

Fajri, Rahmi. (2015). Akuntabilitas Pemerintah Desa Pada Pengelolaan Alokasi Dana Desa (ADD). Jurnal Administrasi Publik (JAP), Vol 3 No.7 Hal 1099-1104.

Faridah. (2015). Transparansi dan Akuntabilitas Pemerintah Desa dalam Pengelolaan Anggaran Pendapatan dan Belanja Desa (APBDES). Jurnal Ilmu dan Riset Akuntansi, Vol. 4 No.1.

Ferina, Ika Sasti. (2016). Tinjauan Kesiapan Pemerintah Desa dalam Implementasi Peraturan Menteri Dalam Negeri Nomor 113 tentang Pengelolaan Keuangan Desa (Studi Kasus pada Pemerintah Desa di Kabupaten Ogan Hir). Jurnal Manajemen dan Bisnis Sriwijaya, Vol.14, No.3 Hal 321-336.

Gamaliel, Hendrick. (2017). Pengaruh Kompetensi Aparat Pengelola Dana Desa, Komitmen Organisasi Pemerintah Desa, dan Partisipasi Masyarakat Terhadap Akuntabilitas
Pengelolaan Dana Desa Di Kabupaten Gorontalo. Jurnal Riset Akuntansi dan Auditing "Goodwill" 8 (2).

Hamid, Alfian. (2016). Transparansi dan Akuntabilitas Pengelolaan Keuangan Alokasi Dana Desa (ADD) Dalam Pencapaian Good Governance.

Irma, Ade. (2015). Akuntabilitas Pengelolaan Alokasi Dana Desa (ADD) di Kecamatan Dolo Kabupaten Sigi. e-jurnal Katalogis, Vol.3 No.1 Hal 121137.

Karimah, Faizatul. (2013). Pengelolaan Alokasi Dana Desa dalam Pemberdayaan Masyarakat (Studi pada Desa Deket Kulon Kecamatan Deket Kabupaten Lamongan. Jurnal Administrasi Publik (JAP). Hal. 597-602.

Kementerian Desa, Pembangunan Daerah Tertinggal, dan Transmigrasi. (2015). Indeks Desa Membangun . Jakarta.

Kim \& Schacter. (2013). Citizen Participation in The Budget Process and Local Government Accountability. Public Performance and Management Review. Hal. 412.

Lembaga Administrasi Negara. (2015). Akuntabilitas dan Good Governance. Jakarta: LAN BPKP RI. 
EAJ (Economics and Accounting Journal) - Vol. 4, No. 1, Jan 2021 - Nazar, et al.

Makalalag, Astri Juainita. (2017). Akuntabilitas Pengelolaan

Dana Desa di Kecamatan

Kotamobagu Selatan Kota

Kotamobagu. Jurnal Riset Akuntansi dan Auditing “Goodwill”. Hal. 149-158.

Niken. (2017). Faktor-Faktor Yang Mempengaruhi Akuntabilitas Pengelolaan Alokasi Dana Desa (Studi Pada Kantor Desa di Kabupaten Ponorogo). Hal 84.

Novia. (2015). Partisipasi Masyarakat Dalam Pemanfaatan Program Alokasi Dana (Studi di desa Semongan Kecamatan Noyan Kabupaten Sanggau). Jurnal Sosiatri Volume 4 Nomor 3.

Riskasari. (2016). Akuntabilitas Pengelolaan Alokasi Dana
Desa di Desa Bongki Lengkese Kecamatan Sinjai Timur Kabupaten Sinjai. Jurnal Office, Hal 126.

Riyanto, Teguh. (2015). Akuntabilitas Finansial Dalam Pengelolaan Alokasi Dana Desa (ADD) di Kantor Desa Perangat Selatan Kecamatan Marangkayu Kabupaten Kutai Kartanegara. Hal 119-130.

Sagala, Rivai. (2013). Manajemen Sumber Daya Manusia untuk Perusahaan. Rajawali Pers.

Wida, S. A. (2016). Akuntabilitas Pengelolaan Alokasi Dana Desa (ADD) di Desa-Desa Kecamatan Rogojampi Kabupaten Banyuwangi. Skripsi. Program studi S1 Akuntansi Fakultas Ekonomi Universitas Jember 